\title{
GOSPODARKA NIEFORMALNA JAKO WYRAZ ZAWODNOŚCI PAŃSTWA
}

\section{WSTĘP}

Obecny rozwój gospodarki nieformalnej powoduje pojawienie się wielu nowych pytań dotyczących współczesnych gospodarek rynkowych. Celem artykutu jest analiza przyczyn rozwoju gospodarki nieformalnej oraz ocena podejmowanych przez państwo środków zmierzających do jej ograniczenia i likwidacji (główna uwaga zostanie zwrócona na funkcjonowanie służb podatkowo-skarbowych w Polsce).

\section{GOSPODARKA NIEFORMALNA - DEFINICJE}

Zjawisko gospodarki nieformalnej jest znane i było omawiane pod różnymi nazwami: gospodarka podziemna ${ }^{1}$, nieoficjalna, nierejestrowana, nieregularna, równoległa, druga, alternatywna, ukryta, niewidzialna, gospodarka cienia lub dorabianie na czarno (moonlighting) itd. W literaturze przedmiotu podkreśla się brak jednolitej definicji gospodarki nieformalnej. Definicja tego zjawiska zależy od celu badań.

Pojęcie gospodarki nieformalnej zwykle obejmuje działalność przynoszącą dochód, która w przeciwieństwie do regulowanej gospodarki formalnej ma miejsce poza formalnymi ramami regulacyjnymi. Regulacja oznacza tutaj zinstytu-

${ }^{1}$ „Gospodarka podziemna” jest ogólnym terminem na określenie kilku rodzajów działalności gospodarczej. Można wyróżnić co najmniej trzy odmienne części gospodarki podziemnej: 1) Działalność przestępcza, która ze swej natury nie mogłaby być prowadzona oficjalnie. Jest ona całkowicie odrębna od pozostałych dwóch rodzajów gospodarki podziemnej; 2) Uchylanie się od płacenia podatków od legalnych form dochodów: wszystkie państwa mają z tym do czynienia i wprowadziły mechanizmy wykrywania i kontroli uchylania się od podatków; 3) Gospodarka nierejestrowana. 
cjonalizowaną ingerencję państwa. Ponieważ cechy pracy nieformalnej wywodzą się $\mathrm{z}$ istnienia kontekstu, gospodarkę nieformalną można zrozumieć wyłącznie w odniesieniu do gospodarki formalnej, tj. regulowanej działalności przynoszącej dochód. Gospodarkę nieformalną można określić tylko dzięki temu, że istnieją instytucjonalne ramy działalności gospodarczej, za pomocą których państwo jednoznacznie ingeruje $\mathrm{w}$ celu regulowania procesów i wyników działalności przynoszącej dochód zgodnie $\mathrm{z}$ istniejącymi regułami prawnymi. Brak takich ram instytucjonalnych pociągałby za sobą brak gospodarki nieformalnej ${ }^{2}$. Zatem działalność w gospodarce podziemnej najczęściej przyjmuje postać:

- działalności prowadzonej bez wymaganych zezwoleń,

- nieprzestrzegania przepisów prawnych regulujących działalność gospodarczą,

- prowadzenia działalności gospodarczej - zarejestrowanej lub nie - i uchylania się od płacenia podatków i parapodatków33.

Do podstawowych przyczyn występowania gospodarki nieformalnej, można zaliczyć:

1. przyczyny ekonomiczne:

- brak lub niewystarczające dochody pracujących,

- brak legalnej pracy,

- obawę przed utratą świadczeń w przypadku rejestracji umowy o pracę (dotyczy np. rencistów i bezrobotnych),

- obniżanie kosztów, aby sprostać konkurencji;

2. przyczyny instytucjonalne:

- wysokie podatki nakładane na pracę,

- wysokie zasiłki dla bezrobotnych,

- regulacje rynku pracy (np. łatwość zwalniania i zatrudniania);

3. przyczyny psychologiczne:

- społeczna moralność podatkowa (rozumiana jako społeczne przyzwolenie na podejmowanie działalności nieformalnej),

${ }^{2}$ S. Sassen, Deformacja w wysoko rozwiniętych gospodarkach rynkowych, [w:] A. Karwińska, A. Surdeja (red.), Wokót zagadnień gospodarki nieformalnej, Wydawnictwo AE w Krakowie, Kraków 2004, s. 29.

${ }^{3}$ K. Dzierżawski, Krótki kurs ekonomii praktycznej, Wydawnictwo Zysk i Spółka, Warszawa 2006, s. 83; zob. też M. Smejda (red.), Szara strefa w okresie transformacji ustrojowej gospodarki polskiej, Wydawnictwo Uniwersytetu Śląskiego, Katowice 1996; G. Chorążykiewicz, Szara strefa, „Życie Gospodarcze” 1993; Szara strefa gospodarki (wybrane problemy), Z Prac Zakładu Badań Statystyczno-Ekonomicznych, z. 223, GUS, Warszawa 1995; Szara gospodarka w Polsce-rozmiary, przyczyny, konsekwencje, Z Prac Zakładu Badań Statystyczno-Ekonomicznych, z. 233, GUS, Warszawa 1996; K. Kloc, Szara strefa w Polsce w okresie transformacji, CAS-E, Warszawa 1998; M. Bochenek, Szara strefa, [w:] B. Polszakiewicz (red.), Problemy gospodarki rynkowej w Polsce, UMK, Toruń 2004; A. Kubiczek, Czy szara strefa w Polsce musi być tak rozlegta?, [w:] B. Polszakiewicz, J. Boehlke (red.), Wtasność i kontrola w teorii i praktyce, UMK, Toruń 2008. 
- skłonność do podejmowania ryzyka.

Badania prowadzone w Polsce potwierdzają występowanie podobnego katalogu przyczyn, a także wskazują, że największy wpływ na tworzenie się gospodarki nieformalnej mają przyczyny o charakterze ekonomicznym ${ }^{4}$. Paradoksalnie można powiedzieć, że jedną z przyczyn wzrostu gospodarki nieformalnej jest fakt istnienia jej w ogóle.

Istnienie i rozwój gospodarki podziemnej stwarza wiele problemów. B. S. Frey i F. Schneider zwracają uwagę na cztery główne grupy problemów: 1) Ocena warunków ekonomicznych i socjalnych obywateli, gospodarstw domowych, przedsiębiorstw i krajów jest niewiarygodna, jeśli opiera się na oficjalnych statystykach (np. oficjalna liczba osób bezrobotnych może nie pokazywać, że w rzeczywistości część z nich jest zatrudniona „na czarno” i otrzymuje dochody z pracy najemnej). Konsekwencją tego może być zbyt ekspansywna polityka makroekonomiczna, a polityka społeczna nadmiernie rozbudowana; 2) Utrata wpływów podatkowych, ponieważ działalność podziemna unika opodatkowania; 3) Gospodarka podziemna jest wskaźnikiem niewłaściwej relacji między obywatelem a rządem. Podatnicy są niezadowoleni z usług publicznych, które otrzymują w zamian za swoje składki i starają się zrekompensować to sobie poprzez ucieczkę w gospodarkę podziemną; 4) Gospodarka podziemna osłabia więzi społeczne, ponieważ sprzyja sytuacji, w której wszyscy kierują się swoim własnym interesem, odrzucając solidarność 5 .

Paradoksalnie istnienie gospodarki podziemnej może być też postrzegane jako pozytywne zjawisko. Gospodarka podziemna jest korzystna, ponieważ odpowiada na zapotrzebowanie otoczenia gospodarczego na pewne usługi i drobna wytwórczość. Sektor nieformalny przydaje gospodarce ducha przedsiębiorczości i może wzmacniać konkurencję, podnosić wydajność. Sektor nieformalny przyczynia się do tworzenia rynków, zwiększa zasoby finansowe i przekształca prawne, społeczne i gospodarcze instytucje. Ponadto znaczna część (do 70\%) dochodów uzyskiwanych w gospodarce cienia jest szybko wydawana w sektorze oficjalnym, a tym samym pobudza gospodarkę oficjalną. Wydatki te zwykle powodują wzrost wydatków konsumpcyjnych, a także (głównie pośrednio) wpływów z podatków ${ }^{6}$.

\section{PAŃSTWO WOBEC GOSPODARKI NIEFORMALNEJ}

${ }^{4}$ Por. M. Grabowski, Nielegalne zatrudnienie w MSP w Polsce, [w:] Pracodawcy-pracobiorcy w sektorze prywatnym, PARP, Warszawa 1997; Praca nierejestrowana w Polsce w 2004 r., GUS, Warszawa 2005.

${ }^{5}$ B. S. Frey, F. Schneider, Ekonomika gospodarki nieformalnej, [w:] A. Karwińska, A. Surdeja (red.), Wokót zagadnień gospodarki nieformalnej, Wydawnictwo AE w Krakowie, Kraków 2004, s. 15.

${ }^{6}$ Ibidem, op. cit., s. 24. 
Gospodarkę nieformalną należy w zasadzie ograniczać i likwidować, poza pewnymi wyjątkami. Tymi wyjątkami mogłyby być usługi pożyteczne społecznie, a jednocześnie trudne do uchwycenia i na ogół o niewielkiej skali (np. odpłatna pomoc sąsiedzka, korepetycje, opieka nad chorymi i starszymi osobami). Za dopuszczeniem niektórych przejawów gospodarki nieformalnej przemawiają względy ekonomiczne - to znaczy zbyt wysokie koszty jej zwalczania w relacji do efektów podatkowych ${ }^{7}$ - oraz względy społeczne w postaci poprawy sytuacji materialnej bezrobotnych czy emerytów ${ }^{8}$.

Jak zatem w Polsce ogranicza się gospodarkę nieformalną? Sposoby zwalczania gospodarki nieformalnej zależą przede wszystkim od jej rodzaju z punktu widzenia jej legalności. Wyróżnić można:

- produkcję i usługi nielegalne, czyli zabronione przez prawo i zwalczane przez policję i służby celne, oraz

- produkcję i usługi ukryte, czyli dozwolone prawem, ale niezarejestrowane i zwalczane przez służby podatkowo-skarbowe.

Działalność gospodarczą można podzielić na trzy typy ze względu na zakres zwalczania szarej strefy:

- działalność zawsze ścigana, jak: przemyt, produkcja i handel narkotykami, przestępstwa gospodarcze i kradzieże na większą skalę;

- działalność ścigana sporadycznie, przy przekroczeniu pewnych granic pod względem skali i czasu trwania, jak np. domowe wytwarzanie alkoholu, drobna spekulacja;

- działalność nieścigana, jak np. korepetycje, drobne naprawy sąsiedzkie9.

W literaturze przedmiotu wyróżniane są dwa główne sposoby ograniczania gospodarki nieformalnej:

1) zmniejszanie kosztów działalności oficjalnej, czyli kosztów przedsiębiorstw zarejestrowanych, poprzez ograniczanie regulacji prawnych i ekonomicznych oraz obniżanie opłat i podatków;

2) zwiększanie kosztów działalności w szarej strefie poprzez wzrost skuteczności służb podatkowo-skarbowych oraz obciążanie karami za obroty nielegalne i nierejestrowane ${ }^{10}$.

Pierwszy sposób oznacza zmniejszenie ingerencji państwa w gospodarkę. Obecnie w Polsce, mimo głoszonych haseł liberalizacji gospodarki, funkcjonuje

${ }^{7}$ Mówiąc o tych wyjątkach, trzeba też zwrócić uwagę na dochód niepodlegający opodatkowaniu zgodnie z zasadami naliczania podatku dochodowego od osób fizycznych (niedeklarowany), który nie stanowi o pracy w szarej strefie.

${ }^{8}$ B. Bachowska, K. Górka, Sposoby ograniczania oszustw podatkowych w Polsce, [w:] A. Karwińska, A. Surdeja (red.), Wokót zagadnień gospodarki nieformalnej, Wydawnictwo AE w Krakowie, Kraków 2004, s. 160.

${ }^{9}$ Ibidem, s. 161.

${ }^{10}$ Ibidem, s. 162. 
duża liczba regulacji i ograniczeń w postaci koncesji, licencji, pozwoleń, a także przeregulowanie rynku pracy, zwłaszcza $\mathrm{w}$ odniesieniu do przedsiębiorstw zatrudniających więcej niż 5 pracowników ${ }^{11}$. Istotną kwestią okazuje się również system podatkowy. Wiadomo, że system skomplikowany i z wysokimi stawkami zwiększa skłonność do podejmowania ryzyka prowadzenia działalności w szarej strefie, nawet przy stosunkowo wysokich karach, natomiast system prosty i niskie podatki obniżają koszty administracji państwowej oraz koszty zarządzania przedsiębiorstwami, a także zmniejszają skłonność do działalności nierejestrowanej. Dodatkową wadą polskiego systemu podatkowego jest brak stabilności przepisów. W najbliższym czasie należy oczekiwać zmian w tym zakresie.

Drugi sposób ograniczania gospodarki nieformalnej wiąże się głównie z organizacją i funkcjonowaniem służb podatkowo-skarbowych i celnych oraz różnego typu inspekcji (Państwowa Inspekcja Pracy, inspektorzy nadzoru budowlanego itp.). W Polsce struktura tych służb jest niedopracowana, są one niedostatecznie wyposażone w środki prawne, materialne (komputery, kopiarki itp.) oraz kadrowe. Przepisy prawne, w tym ustawy, są w wielu przypadkach niejasne, a nawet sprzeczne.

\section{OSZUSTWA PODATKOWE I CELNE}

Obecnie w Polsce przedsiębiorca podejmuje działalność gospodarczą na podstawie wpisu do ewidencji działalności gospodarczej w gminie (dotyczy to osób fizycznych i spółek cywilnych) lub do rejestru przedsiębiorców (dotyczy to osób prawnych), poprzez sąd rejonowy, w Krajowym Rejestrze Sądowym, co stanowi czynnik kontroli. Przedsiębiorca składa też wniosek o wpis do krajowego rejestru urzędowego podmiotów gospodarki narodowej REGON oraz zgłoszenie identyfikacyjne podatników i płatników. Przedsiębiorca jest ponadto zobowiązany do dokonywania i przyjmowania płatności (o równowartości od 3 tysięcy euro) za pośrednictwem rachunku bankowego, co stanowi kolejny czynnik formalizujący gospodarkę.

Tymczasem sposobów nieprawidłowego zmniejszania przez przedsiębiorstwa ich zobowiązań podatkowych i celnych jest wiele. Do najczęstszych należą:

- zatrudnianie pracowników „na czarno” w celu zmniejszenia kosztów pracy ${ }^{12}$;

${ }^{11}$ Według ocen przedsiębiorców z Business Center Club w polskim systemie gospodarczym występuje ok. 200 obszarów działalności gospodarczej, które podlegają różnym regulacjom, takim jak: zezwolenia, pozwolenia, zgody, upoważnienia i licencje (Zakazaćzakazów, „Nowe Życie Gospodarcze” 2000, nr 22); prawem blokującym przedsiębiorczość zajmuje się m.in. sejmowa komisja „Przyjazne państwo” (J. Palikot).

${ }^{12}$ Według danych GUS w 2004 r. w szarej strefie pracowało 1,317 mln osób, co stanowiło 
- sztuczne zwiększanie tzw. kosztów uzyskania przychodów, co umożliwia niezasłużoną obniżkę opodatkowania dochodów z działalności gospodarczej (nie tyle z powodu słabości tej kategorii, ile niejasności przepisów). Dotyczy to również rozliczania holdingów (powiązanych ze sobą spółek, w tym z zagranicznymi spółkami-matkami) - transfer dochodów za granicę ${ }^{13}$;

- manipulowanie podatkiem VAT - dokonuje się odliczania podatku od towarów i usług $\mathrm{z}$ faktur wystawionych przez podatników VAT, ale dokumentujących fikcyjne lub przewartościowane transakcje. Przedsiębiorcy często z opóźnieniem wystawiają faktury VAT dokumentujące sprzedaż czy usługę. Eksporterzy podrabiają dokumenty przewozowe w celu wyłudzenia podatku VAT. Niektórzy przedsiębiorcy ukrywają przychody, nie wydając paragonów lub wydając paragony niefiskalne ${ }^{14}$;

- z pogranicza czarnej sfery (działalność przestępcza) ${ }^{15}$ : obrót paliwami płynnymi ${ }^{16}$, obrót alkoholem etylowym ${ }^{17}$, obrót wyrobami tytoniowymi ${ }^{18}$, nielegalny handel i hazard w Internecie ${ }^{19}$.

9,6\% ogólnej liczby pracujących. Więcej na temat pracy „na czarno” zob. Praca nierejestrowana w Polsce w 2004...; według najnowszych danych szacunkowych w „szarej gospodarce” liczba pracujących wyniosła w 2005 r. 1,035 mln osób, w 2006 - 1,076 mln osób, w 2007 - 1,131 mln osób, w 2008 - 1,168 mln osób; Maty Rocznik Statystyczny Polski 2009, GUS, Warszawa 2009, s. 137; http://www.stat.gov.pl (13.09.2009).

${ }^{13}$ Organy kontroli skarbowej w 2005 r. przeprowadziły kontrolę 108 podatników, które skutkowały ustaleniami w podatku dochodowym w łącznej kwocie 10 mln zł i VAT w kwocie 0,9 mln zł oraz obniżeniem straty w wysokości $19 \mathrm{mln}$ zł. Transakcje z podmiotami powiązanymi były również przedmiotem kontroli. W 2005 r. urzędy skarbowe skontrolowały 2039 podmiotów, w wyniku czego dokonano ustaleń na ogólną kwotę $56 \mathrm{mln}$ zł; http://www.mf.gov.pl (13.09.2009).

${ }^{14}$ B. Bachowska, K. Górka, op. cit., s. 165.

15 Informacja o funkcjonowaniu "szarej strefy” w polskiej gospodarce i przeciwdziatanie jej przez stużby skarbowe, http://www.mf.gov.pl (13.09.2009).

${ }_{16}$ Eksperci branżowi (Polska Izba Paliw Płynnych) szacują - na podstawie wyników kontroli stacji, jakie przeprowadziła Inspekcja Handlowa, i badania próbek paliw przeprowadzonych w Centralnym Laboratorium Naftowym - w obrocie detalicznym szarą strefę na ok. 2-3 mld zł w skali roku. Hipotetyczne straty Skarbu Państwa z tego tytułu (VAT i akcyza) wynoszą więc około 1,4 mld w skali roku; http://www.mf.gov.pl (13.09.2009).

${ }^{17}$ Skalę zjawiska trudno oszacować. Służba celna w 2005 r. dokonała zajęcia na granicy państwa 117 tys. litrów przemycanych wyrobów alkoholowych. Pracownicy szczególnego nadzoru podatkowego z urzędów celnych podczas kontroli rynku wewnętrznego w 2005 r. dokonali zajęcia 12,8 tys. litrów alkoholu etylowego (w przeliczeniu na alkohol 100\%) bez akcyzy; http://www. mf.gov.pl (13.09.2009).

${ }_{18}$ Służba celna w 2005 r. dokonała zajęcia na granicy państwa $425 \mathrm{mln}$ szt. przemycanych wyrobów tytoniowych. Pracownicy szczególnego nadzoru podatkowego z urzędów celnych podczas kontroli rynku wewnętrznego w 2005 r. dokonali zajęcia 429 tys. paczek wyrobów tytoniowych bez znaków akcyzy; http://www.mf.gov.pl (13.09.2009).

${ }^{19}$ Według danych prasy branżowej liczba osób korzystających z Internetu w Polsce to 8-9 mln, a obroty handlowe w 2005 r. szacowano na 1,7 mld zł (w 2007 r. szacunek ten sięga już 3,7 mld zł). Istnieją też firmy wykorzystujące Internet, prowadząc jednocześnie marketing e-hazardu. Zlokalizowane są zwykle poza granicami Polski, na terenie tzw. rajów podatkowych. 
Identyfikacja oszustw podatkowych i ocen ich skutków finansowych ułatwia walkę z szarą strefą. Szacuje się, że oszustwa podatkowe i celne przedsiębiorstw zarejestrowanych stanowią 65-70\% dochodów gospodarki nieformalnej i dlatego należy zabiegać o ich ograniczenie ${ }^{20}$.

\section{KONSEKWENCJE DLA POLITYKI}

Polska, dostosowując się do standardów w Unii Europejskiej, powinna dążyć do zmniejszenia gospodarki nieformalnej w PKB z obecnych 15\% (tab. 1) do poniżej 5\% $\mathrm{PKB}^{21}$.

Tabela 1. Szacunki rozmiarów „szarej gospodarki” w tworzeniu PKB w latach 2000-2007 w cenach bieżących

\begin{tabular}{|l|r|r|r|r|r|r|r|r|}
\hline WYSZCZEGóLNIENIE & \multicolumn{1}{|c|}{2000} & \multicolumn{1}{|c|}{2001} & \multicolumn{1}{c|}{2002} & \multicolumn{1}{c|}{2003} & 2004 & 2005 & 2006 & 2007 \\
\hline $\begin{array}{l}\text { Szara gospodarka jako } \% \\
\text { PKB, w tym: }\end{array}$ & $17,0 \%$ & $16,8 \%$ & $15,4 \%$ & $15,8 \%$ & $14,5 \%$ & $15,9 \%$ & $15,9 \%$ & $14,7 \%$ \\
\hline $\begin{array}{l}\text { W jednostkach zarejestro- } \\
\text { wanych }\end{array}$ & $11,7 \%$ & $11,6 \%$ & $10,2 \%$ & $10,7 \%$ & $9,6 \%$ & $11,0 \%$ & $11,2 \%$ & $10,5 \%$ \\
\hline $\begin{array}{l}\text { Z tytułu wykonywania pra- } \\
\text { cy nierejestrowanej }\end{array}$ & $5,3 \%$ & $5,2 \%$ & $5,2 \%$ & $5,1 \%$ & $4,9 \%$ & $4,9 \%$ & $4,7 \%$ & $4,2 \%$ \\
\hline
\end{tabular}

Źródło: Rachunki narodowe według sektorów i podsektorów instytucjonalnych 2000-2006, Studia i Analizy Statystyczne, GUS, Warszawa 2008, s. 611; Rachunki narodowe według sektorów i podsektorów instytucjonalnych 2005-2007, Studia i Analizy Statystyczne, GUS, Warszawa 2009, s. 317.

W najbliższym czasie nie należy oczekiwać zmniejszenia kosztów działalności oficjalnej, dlatego do ograniczania gospodarki nieformalnej powinny przystąpić służby skarbowe. Warto byłoby usprawnić działanie systemu kontroli podatkowej i skarbowej.

Należałoby zacząć od niedostatecznego monitorowania działalności gospodarczej. Mimo intencji tworzenia centralnej bazy danych w Krajowym Rejestrze Sądowym, jeszcze nie wszyscy przedsiębiorcy są zobligowani do dokonania takiej rejestracji. Niedoskonały jest również system REGON prowadzony przez GUS.

Dużym problemem jest niewystarczające osadzenie służb podatkowo-skarbowych w przepisach prawnych. W szczególności chodzi o zbyt elastyczne sformułowania i interpretacje np. kosztów uzyskania przychodów. Problem ten mogłoby

Obieg gotówkowy związany z opisaną działalnością odbywa się poprzez konta bankowe lub poprzez SMS-y w sposób trudny do skontrolowania; http://www.mf.gov.pl (13.09.2009).

${ }^{20}$ B. Bachowska, K. Górka, op. cit., s. 163-164.

${ }^{21}$ Ibidem, s. 162 . 
rozwiązać przyznanie przedsiębiorstwom zryczałtowanych kosztów uzyskania przychodów (np. jak to mają twórcy - w wysokości 50\%). Innym kłopotliwym i mało uzasadnionym rozwiązaniem jest przyjęcie w polityce podatkowej systemu memoriałowego, w którym przedsiębiorca jest zobowiązany do płacenia podatku dochodowego i VAT po wystawieniu faktury, co sprzyja oszustwom, a także ułatwia przedsiębiorstwom dominującym na rynku wymuszanie na dostawcach wielomiesięcznych kredytów kupieckich. Wprowadzenie systemu kasowego oznaczałoby powstanie obowiązku podatkowego dopiero $\mathrm{z}$ chwilą otrzymania zapłaty za sprzedany towar lub usługę 22 .

Zastrzeżenia może budzić też potencjał kadrowy tych służb skarbowych, w tym znajomość prawa cywilnego i administracyjnego oraz księgowości przez inspektorów. Wynika to m.in. z braku specjalizacji pracowników kontroli, gdy tymczasem podmioty gospodarcze i ich problemy są bardzo zróżnicowane. Dodatkowo liczba kontroli skarbowych jest zbyt niska. Prawdopodobieństwo kontroli przedsiębiorstwa w danym roku podatkowym wynosi około 0,3\%. Zatem przedsiębiorstwo jest kontrolowane w Polsce przeciętnie co 3-4 lata, gdy tymczasem w większości krajów UE corocznie. Jest to rezultat relatywnie niskiego zatrudnienia w służbach podatkowo-skarbowych w Polsce oraz mniejszej ich sprawności. Szczególnie niska jest liczba tzw. krzyżowych kontroli faktur, zapewniających ujawnianie oszustw ${ }^{23}$.

Urzędy skarbowe w niedostateczny sposób wykorzystują informacje podatkowe o transakcjach napływające od notariuszy, sądów, banków, organów administracji rządowej i samorządowej, jak również podmiotów gospodarczych. Jest to spowodowane brakiem jednolitego systemu informatycznego. Urzędy skarbowe prowadzą małą liczbę postępowań podatkowych w związku z określaniem wysokości przychodów, które nie znajdują pokrycia w ujawnionych źródłach lub pochodzą ze źródeł nieujawnionych (podatek wynosi wtedy 75\% przychodów). Za naganne można uznać nieegzekwowanie - bez większego uzasadnienia - górnych stawek kar wymierzanych przez urzędy kontroli skarbowej. Wprawdzie jest zasada, że kary powinny być nie tyle wysokie, ile nieuchronne i szybko egzekwowalne, ale także ona nie zawsze działa.

Legalność zatrudnienia też jest słabo kontrolowana w Polsce. Państwowa Inspekcja Pracy, powołana do tego zadania, nie ma odpowiednich środków. Niekiedy kontrolę zatrudnienia przeprowadzają powiatowe urzędy pracy, w ramach walki z bezrobociem, oraz ZUS. Poza kontrolami ZUS-u i urzędów pracy wobec obywateli polskich duże znaczenie mają również kontrole wobec cudzoziemców.

\footnotetext{
${ }^{22}$ Ibidem, s. 169.

${ }^{23}$ Ibidem, s. 170.
} 
Niezadowalający system kontroli można również odnieść do jakości sprzedawanych towarów i legalności przyrządów pomiarowych (np. jakość paliwa do samochodów).

W podsumowaniu można wspomnieć o niesprzyjającej atmosferze wokół służb podatkowo-skarbowych. Media piętnują często potknięcia urzędów skarbowych, a bez większego odzewu pozostaje oszukiwanie fiskusa przez wielu przedsiębiorców. Nadal w świadomości Polaków górę bierze skłonność do chlubienia się takim oszukiwaniem, a nie jak w bogatych krajach - duma z wysokości zapłaconych podatków ${ }^{24}$.

\section{ZAKOŃCZENIE}

Gospodarka nieformalna nie jest łatwym obszarem badawczym, czego dowodem są toczące się dyskusje definicyjne i rozbieżności w sposobie i zakresie postrzegania „nieformalności” różnych przejawów działalności gospodarczej. Problemem do rozwiązania są ponadto zagadnienia pomiaru gospodarki nieformalnej oraz określanie i ocenianie wpływu funkcjonowania tego rodzaju gospodarki na gospodarkę oficjalną, przebieg zjawisk społecznych czy na politykę państwa.

Można powiedzieć, że rozrost gospodarki nieformalnej wynika $\mathrm{z}$ istnienia barier ekonomicznych (o charakterze regulacyjnym) oraz barier fiskalnych. Obserwując aktualną sytuację w Polsce, można przypuszczać, że decyzja o funkcjonowaniu w strefie nieoficjalnej zdeterminowana jest głównie problemami z fiskalizmem, a dopiero $\mathrm{w}$ drugiej kolejności $\mathrm{z}$ oddziaływaniem zbiurokratyzowanej gospodarki.

Polityka państwa może w dziedzinie ograniczania gospodarki nieformalnej wiele zdziałać poprzez tzw. deregulację i liberalizację systemu zarządzania gospodarką oraz reformę systemu ubezpieczeń społecznych i inne zachęty do legalizacji działalności gospodarczej i ujawniania pełnych obrotów. Bardzo ważne są również kontrole. Ostatnio gospodarka nieformalna staje się problemem w wielkich firmach, powiązanych $z$ kapitałem zagranicznym, co wymaga dostosowania przepisów prawa do nowych warunków gospodarowania i procesów globalizacji, a także wzmocnienia służb podatkowo-skarbowych.

Niemniej jednak, należy zaznaczyć, że nieformalna strefa występuje w każdej gospodarce. Jest ona wynikiem nieprzestrzegania określonych reguł gry społeczno-gospodarczej.

\section{INFORMAL ECONOMY AS AN EXPRESSION OF THE STATE FAILURE}

\footnotetext{
${ }^{24}$ Ibidem, s. 171.
} 


\section{SUMMARY}

The article deals with the phenomenon of a second economy, underground or subterranean economy, unofficial economy, unrecorded economy, informal economy, cash economy etc., which has been assessed here as a function of a given mix of economic policies. This key concept is first defined, then analysed. The analysis contains quantitative data illustrating the scale of the underground economy in Poland. Having catalogued the principal reasons for the prevalence of the informal economy, the analysis formulates policy orientated conclusions relating to specific areas where there needs to be reform. 